\title{
Editorial: Lifelong Learning - at a Price
}

Lifelong learning is a deeply humane idea, with an honourable pedigree in Britain in the work of the great Victorian sages John Ruskin, William Morris, Matthew Arnold and more remotely Thomas Carlyle. In their writings and, in Ruskin's case at least, in his practical campaigning too, these men did much to awaken among the working classes a desire for intellectual and spiritual nourishment, and nourishment from the best that had been thought and known. Not for nothing did these aspirations lead to a great upsurge in what was called workers' or adult education, and not for nothing were these efforts at the end of the nineteenth century often focused on the trade unions and the embryonic Labour party, an honourable heritage indeed.

Institutions at university level were set up specifically to meet the demand among mature working people for genuine education, such as Birkbeck College in London, Ruskin College in Oxford, and much later in the twentieth century The Open University. In all these cases, and in adult education more generally, the underlying principle has always been that what is provided will be affordable to those who genuinely want it, irrespective of direct financial benefits to either student or to the economy generally. Not surprisingly subjects like philosophy, history, literature and the arts have flourished in the environment of adult education, for it is often mature, working people who come later in life to have a deep thirst for what liberal education has to offer. In Britain we have prided ourselves on the availability of liberal education to those who have missed out on it in their youth, taking this to be a mark of our civilisation.

Not any more, it seems. In order to save $£ 100$ million from the education budget and to re-direct it to employment based schemes the Government is currently proposing to make adults who have already got one degree (getting on for $40 \%$ of the age group these days) pay what are called full cost fees for any further qualification they take at the same level. As full cost fees are currently around $£ 8,000$ per year, and set to rise sharply in the next few years, someone with a degree in computing or pharmacology, say, who later wanted to read for a degree in philosophy or history would have to pay something like $£ 30,000$ for the privilege. 


\section{Editorial}

The Government's line of defence is that the money thus saved will be directed at people who have not had any higher education. The people will enter what is called a 'train to gain' programme. This is disingenuous even on its own terms. With the lamentable performance of far too many schools in Britain, it is not as if there are crowds of well-qualified candidates currently unable to get into universities to read serious subjects at degree level. The as yet unproven train to gain scheme looks suspiciously like a desperate attempt to put right what has gone wrong in schools, and which should be put right at a much earlier stage of education. But even if this were not so, and there were a genuine unmet demand for degrees, there is still the question of lifelong learning and a civilised society. The Government continually tells us that how important lifelong learning is and what value it puts on it. But New Labour not being Old Labour, in philosophy and the other liberal arts, this value is not what the Government puts into the pot. The value of lifelong liberal learning appears to be what it will in future cost the learner. 